Ngubane, N. \& Brooks, S. (2013). Land beneficiaries as game farmers: conservation, land reform and the invention of the 'community game farm' in KwaZulu-Natal. Journal of Contemporary African Studies, 31(3): 399-420

\title{
Land beneficiaries as game farmers: conservation, land reform and the invention of the 'community game farm' in KwaZulu-Natal
}

\author{
Mnqobi Ngubane and Shirley Brooks
}

\begin{abstract}
Scholarship on post-apartheid land reform includes research on land claims made to formal protected areas, such as national parks and state game reserves. Little attention has however, been paid to the question of land restitution claims on private lands, on which a range of nominally 'conservation-friendly' land-uses (including commercial hunting) have taken place. This article traces the emergence of the 'community game farm' as a product of land reform processes affecting freehold land in the midlands of KwaZulu-Natal province, South Africa. Two groups of land beneficiaries who were granted title to former privately owned game farms used for leisure hunting are studied in detail. The article shows that a range of state and private actors, as well as traditional authorities, have worked to ensure the continuation of the land under conservation or game farming after transfer. The central argument is that in this process, a generic narrative is imposed which works to conflate or deny the distinct historical identities of the beneficiary groups. The article raises questions about the real efficacy of land restitution in this context, as well as the appropriateness of a community-based conservation narrative when applied in the context of small farms such as those considered here.
\end{abstract}

This article considers a significant land-use change evident in the South African countryside the conversion of private farmland to various forms of game or wildlife production. ${ }^{1}$ While the concept of private game reserves is not new, changes in laws enabling the private ownership of wildlife have meant that, in the latter part of the twentieth century, wildlife on farms was 'transformed from a burden to an asset for landowners [resulting in] a rapid shift from livestock to game ranching across large areas of Southern Africa' (Lindsey, Romañ ach, and Davies-Mostert 2009, 100). The shift has taken a number of forms, from game farms offering hunting packages to generate an income; to private game reserves with upmarket tourist lodges; to property developments in the form of luxury lifestyle estates (see Brooks et al. 2011). In post-apartheid South Africa, a number of factors have fuelled this trend. They include: the growth of the tourism industry as the country reconfigured its place in the world economy; the reduced profitability of cattle farming, partly due to the removal of state subsidies for agriculture; an increase in stock theft; and landowners' reactions to new labour and land rights legislation (Carruthers 2008; Cousins, Sadler, and Evans 2008).

Game farming is being superimposed on cultural landscapes shaped by other land-uses and histories. Our geographical focus in this article is the province of KwaZulu-Natal, in particular its central interior. The area known locally as the midlands starts at 
Pietermaritzburg and extends north through grasslands to the 'thornveld' of the Thukela River Valley. To the north of Ladysmith is a higher-lying area of 'sourveld' (see Figure 1). Viewed as a whole, the current land tenure pattern of this region dates back to the mid-nineteenth century, when colonial-era land dispossession led to the introduction of private property and the division of territory in the Natal Colony into two main categories: so-called native reserves, and generous plots of freehold land to be owned by individual farmers. During the twentieth century, this landscape has been subject to various forms of displacement and racially-based dispossession, including the state's attempts to outlaw the widespread practice of labour tenancy (Surplus People Project 1983) and the forced removal of so-called black spots, African-owned land located in 'white' farming areas. In general, the more recent move to game farming may be viewed as a further chapter in this story of dispossession. Hart and Hunter $(2004,916)$ for example argue that the 'vicissitudes of pervasive labour tenancy in this part of Natal trace an arc of dispossession from the nineteenth century to the present, as ongoing evictions of labour tenants make way for game farms'. Land rights NGOs in the region have reported an increase in the number of farm dwellers displaced by game farms (AFRA 2004).

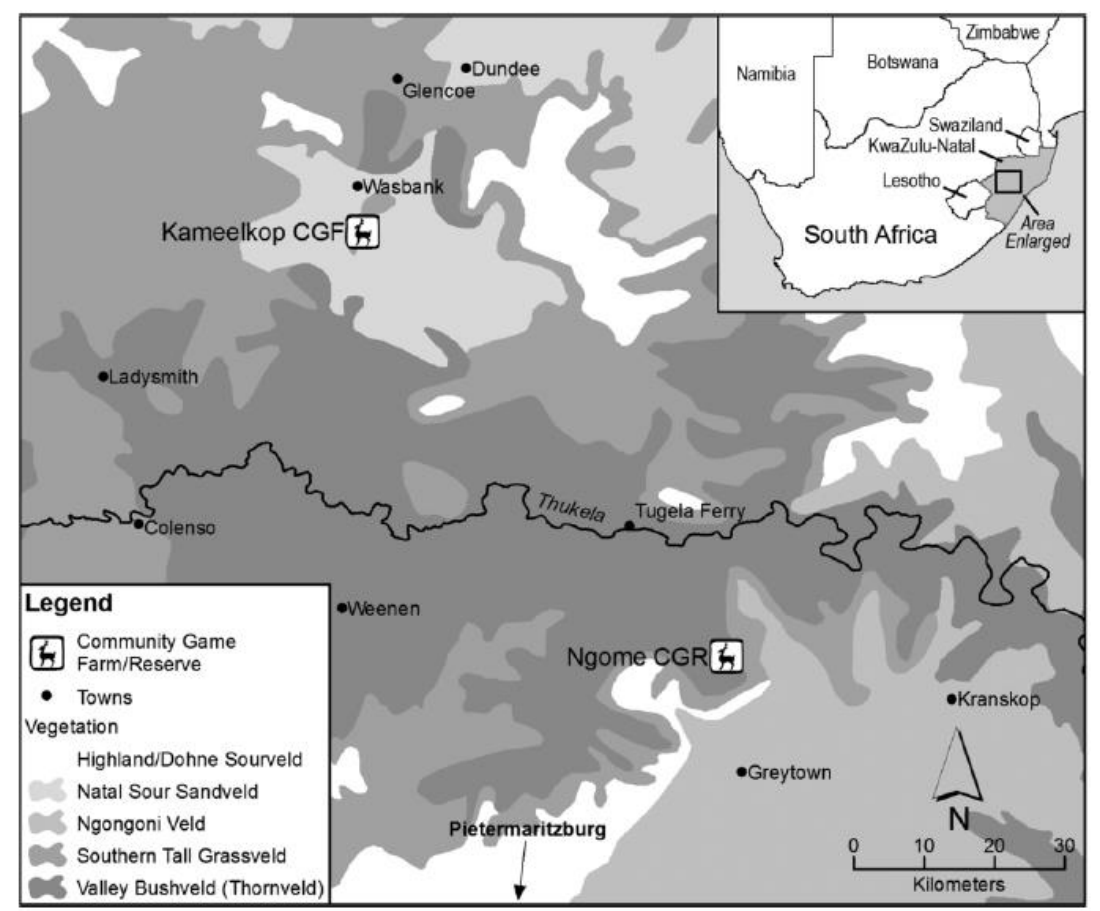

Figure 1. Map of the KwaZulu-Natal midlands with the two game farms indicated.

The main focus of this article is not, however, on displaced farm dwellers. Instead we explore the recent experience of two groups of people seen as beneficiaries of this land-use change. These are people who were dispossessed of land during the apartheid period and who entered into the South African state's land reform process in the hope of getting their land back. In the two cases examined here, the successful land beneficiaries now find themselves in the position of being the new owners of land already converted to game farming by its previous owners. The article seeks to examine the often problematic dynamics of game farming when proffered as a solution in the context of land reform.

Game farming as an already established land-use practice on the newly acquired land is presented to land beneficiaries as, in the first place, a means of livelihood. Confronted by the evidence of a number of failed land reform projects, the state clearly hopes that these game 
farming enterprises will succeed where others have not. Yet game farming differs from forms of conventional agriculture in that it brings with it a set of ideas about conservation, drawn largely from the ideology and practice of community-based conservation (CBC). Game farm beneficiaries have entered into partnerships with state and especially private organisations that are able and willing to offer them wildlife management skills. Whether advising the new owners on management practice, or actually managing the game farm and associated hunting enterprises on their behalf, these partners are steeped in a conservationist discourse that reconstructs land beneficiaries as 'communities' and powerfully promotes game farming as a profitable and 'conservation-friendly' land-use option. In this process, the differing histories and relations to the land of beneficiary communities are smoothed out and disappear, and new power relations arise that call for careful interrogation.

\section{Conservation and land claims in the South African context}

To date, the literature on land claims and nature conservation in South Africa has focused on groups laying claim to state-run protected areas. The history of forced removals for conservation forms an important strand in the history of land dispossession in southern Africa as a whole (Fabricius, Koch, and Magome 2001; Ramutsindela 2003), and land claims have been seen as a strong mechanism for correcting the balance of power between communities and conservation authorities in the region (Reid 2001, 138). In the context of post-apartheid South Africa, Ramutsindela notes that claims on formal conservation land do legitimately fall under the Restitution of Land Rights Act (1994), which is 'concerned with all victims of racially motivated removals in both urban and rural areas [which includes] people who were removed from areas earmarked for national parks and nature reserves' (Ramutsindela 2003, 43).

However effective lobbying by conservationists has ensured that restituted lands are not taken out of conservation management (Ramutsindela 2002; Lahiff 2009). A cabinet memorandum has asserted, controversially, that 'conservation is a land management issue (land use) and not a land ownership issue' (AFRA 2003, 7), and land rights have been 'returned' to communities in terms of agreements that insist on the continuation of conservation management (Manjengwa 2006). The Makuleke land claim in Limpopo province, settled on 30 May 1998, was a landmark case in this regard (Ramutsindela 2002). The implications of the official policy on conservation land are summarised by Lahiff (2009, 98):

Much of the land transferred (or 'delivered', to use the official term) under the restitution programme has been transferred in nominal ownership only, as it remains incorporated into nature reserves and state forests and, in terms of restitution agreements, is not accessible for direct use by the restored owners.

There are a number of options or models for the management of so-called communityowned protected areas, including co-management structures and agree- ments that cater for skills transfer, where claimants are considered unprepared to take on their management responsibilities (AFRA 2003). A radical question posed by scholars is whether this really constitutes restitution in the full sense of the word (Ramutsindela 2002; Walker 2008). Kepe, Wynberg, and Ellis $(2003,19)$ likewise point out that: 
While they may have won their land rights on paper, in practice local communities are often at the mercy of conservation agencies who tend to pursue conservation goals and the prevention of the consumptive use of natural resources [by these communities] at all costs.

Little attention has thus far been paid in the literature to the outcomes of land reform processes on conservation land outside of formal protected areas. In the case of land beneficiaries who have been awarded functioning private game farms as part of the restitution process, a number of themes can be identified that echo the developments outlined above. In the context of KwaZulu-Natal, the provincial conservation agency has played a strong advisory role and facilitated partnerships with private sector players able to offer wildlife management expertise. As in the case of state conservation land, a persuasive argument has been made for wildlife production or 'conservation' to remain the land-use after the land transfer has taken place. In the case of the two game farms considered here, land beneficiaries have partnered with a private sector organisation, the KwaZulu-Natal Hunting and Conservation Association (KZNHCA), which advises on wildlife management and runs the actual hunting operation.

At one level, this is comparable to other agricultural endeavours on restituted land, where those formerly in control of the land may be reconstituted as farming 'mentors' (Walker 2008). However, game farming differs significantly from more conventional farming activities because it is inextricably interwoven with conservationist narratives and ideologies. Along with these partnership arrangements has come a powerful set of ideas about conservation on socalled community land. These ideas come from the southern African experience in which conservationists have attempted to link livelihoods to wildlife protection through CBC initiatives (Tyman 2000; Hulme and Murphree 2001; Logan and Moseley 2002; Blaikie 2006). As in the context of state conservation areas, it is important to unpack the generic notion of 'the community' in wildlife-based land reform initiatives on private land, and to critically examine the process through which very different groups of beneficiaries are conflated into a single category. It is also appropriate to raise questions about the real efficacy of restitution for the new owners of the land. Ideas about CBC were developed in the context of extensive communal lands; these concepts may be less than appropriate to the small game farming operations conducted on farms considered here. We will argue that this (re)conceptualisation is, however, functional for stakeholders in the sector.

\section{Conservation narratives and the role of partner organisations in 'inventing' the community game farm}

Our research focused on two midlands game farms that have been transferred to land beneficiaries: Bhambatha's Kraal Private Game Reserve, renamed Ngome Community Game Reserve, near Ladysmith, and Kameelkop Game Farm (now the Kameelkop Community Game Farm), near Greytown (see Figure 1). ${ }^{2}$ In both cases, the involvement of outside partners in the form of a provincial state department and a private sector organisation - the KZNHCA - has been influential in the process characterised here as the invention of the community game farm in the KwaZuluNatal province. We begin by looking at the way outside 'experts' have reconceptualised these spaces and their new owners, discursively recasting them as a single generic 
category in a new language derived from the world of biodiversity conservation and, more specifically, that of CBC.

\section{Ezemvelo KwaZulu-Natal Wildlife (EKZNW)}

The provincial conservation authority, EKZNW, has been instrumental in promoting the continuation of game farming as a land-use by land beneficiaries. While game farms as privately owned spaces do not form part of the formal conservation estate, EKZNW is quite closely involved in private game farming due to the fact that it is tasked with overall control of wildlife and hunting in the province. No wildlife can be moved or hunted without a permit issued by the agency. In the case of the new 'community game farms', its involvement goes deeper than the usual conducting of annual inspections and the issuing of hunting permits. The provincial conservation authority has constructed its role here in a particular way. Unlike in a formal protected area, it is not directly involved in managing the transferred game farms; however the conservation authority sees itself as in some sense in partnership with the Department of Rural Development and Land Reform (formerly the Department of Land Affairs), which negotiates and oversees the land transfer itself. As an official from EKZNW put it, 'Land Affairs has given them [the beneficiaries] land. It is our role again to say that this is a biodiversity issue, and come in from that angle' (Interview with EKZNW official, July 2009).

EKZNW is interested not only in protected areas under its direct control, but also in the extensive communal lands under customary tenure, where it attempts to spread the message of biodiversity protection by drawing on the CBC narrative. This construction is readily extended to game farms transferred to land beneficiaries. One official outlined his understanding of the conservation agency's role at Kameelkop Community Game Farm. It is clear from this quotation that he views Kameelkop's new landowners in very much the same terms as so-called surrounding communities that is, black communities living adjacent to state protected areas:

In order for the conservation of biodiversity to be meaningful it has to take into account community involvement. Biodiversity conservation has to acknowledge the surrounding communities. In fact we conserve biodiversity inside and outside of protected areas, whether in Kameelkop or not. In other words, we have continuous relations with Kameelkop. Our [community] relations form a core function in our duties. We as an organization - we are there to support and advise them. (Interview with EKZNW official, August 2010)

Another form of involvement also emphasised this understanding. EKZNW invited not only the members of the new land trusts, but also chiefs or traditional authorities to attend nature conservation workshops intended to impart conservation knowledge to the new landowners. The fact that traditional authorities were often in the forefront of the land claim makes them important role players, together with the conservation agency, in the creation of the community game farm. This is illustrated in the following comment on the part of the chief who championed this claim, resulting in the acquisition of Kameelkop Game Farm: 
I had to teach them [the beneficiaries] to respect and love animals so that the future generations will also see them ... I had to teach them not to chop down trees and vegetation; the game farm is not there for firewood. Even the grass is not there for us to burn, but for the animals to graze on ... Those were amongst the things we had to do in order to train people on what they should do. I got that knowledge from ... the Nature Conservation people, who taught us about nature conservation. (Interview with Inkosi Kunene, July 2010)

In the case of Kameelkop Community Game Farm, the provincial conservation agency extended its involvement by negotiating for a former EKZNW employee to be hired by the new land Trust as manager of the game farm. As an official from the conservation authority put it, 'Land Affairs would not have known what kind of person is needed - they just provided money [to buy the land] .. . our involvement comes in because it is our discipline'. The conservation agency approached the land Trust and 'told them about a retired guy who has good experience - that's why Mr X is here [as farm manager]' (Interview with EKZNW official, Kameelkop, July 2009).

At one level, this is a value-neutral development based on practical realities on the ground, in particular the fact that the land beneficiaries have not owned or managed a game farm before. At another level though, it must be recognised that Communal Property Associations (CPAs) or land trusts entering into partnerships with farming and (in this case) conservation 'experts' are also entering into a set of power relations that shape their future in particular ways. Hebinck, Fay, and Kondlo (2011) discuss the role of partner institutions in agriculture, arguing that the appointment of farm mentors who possess the requisite 'expert' knowledge usually works to ensure the continuity of land-use after land is transferred to land beneficiaries. This is quite evident in the case of game farms, with the added element of a prescriptive land-use discourse articulated around biodiversity conservation concerns.

\section{The KwaZulu-Natal Hunting and Conservation Association (KZNHCA)}

A second 'expert' organisation has also become involved with the game farms under review. While the role of EKZNW is necessarily limited to an advisory capacity, the conservation agency suggested the closer involvement of a private organisation, the KZNHCA, and effected the introductions. This private sector association is involved at both Kameelkop Community Game Farm and at Ngome Community Game Reserve, running the commercial hunting operation at both game farms in terms of signed partnership agreements. The advantage for the land Trusts is that they do not need to engage in marketing the farms so as to locate hunting clients or organise professional hunting packages; all this is done by the private sector partner from its head office in Durban.

The hunting association's narrative with regard to the 'community game farms' is one of urgently needed biodiversity education. KZNHCA is concerned to position itself as a conservation organisation, not just a body that facilitates leisure hunting for its members: 
Until now, we were essentially a hunting association, but [now] we call ourselves KZN Hunting and Conservation. The conservation up till now was isolated activities. Our approach is new now .. . We need to manage biodiversity .. . We have to look at the total environmental systems and we have to manage that. It is essential that we hunt here [at Kameelkop], because it is a fenced area and it's an isolated animal population, so there will be growth beyond the carrying capacity ... But hunting is not the first and foremost thing we want to do. For us to be able to harvest the Impala, it must have land to live on, it must have food, it must have water, it must have shelter. All those systems to make this a viable entity must be managed. We must look at the earth in its totality. We can't look at individual elements. That is what we want to teach the people. (Interview with KZNHCA official, July 2010)

The following quote from the same interview is revealing of the way the KZNHCA, like the provincial conservation authority, conflates different groups of land beneficiaries to create a single category of people - (black) 'communities' who now own land, but who do not know how to use it responsibly, and who therefore need to be taught the principles of CBC:

The challenge that we face here is a simple one; here [at Kameelkop Community Game Farm] and in Bhambatha's [Ngome Community Game Reserve]. That is [that] the skills level of the people involved is completely inadequate to make what they got [from government] into a viable enterprise. The people are not educated from an academic perspective. The approach to what they have is still a very traditional approach. It's there to be used: you chop the tree, and you eat the meat. Which is short term. I think what we want to do essentially is to establish a longer term management approach with both the communities. (Interview with KZNHCA official, July 2010)

This construction ignores the complexity of the individual histories described in the next section, eliding them into a single narrative and in the process constructing these land beneficiaries as ignorant and in need of re-education. Such a formulation speaks, of course, to a wider dynamic present in a number of conservation contexts, not only in South Africa. It also fails to understand the significant ambiguities associated with the actual processes of restitution. These begin to emerge in the next section.

\section{How land reform created 'community game farms' on private land in KwaZulu-Natal: Two geographies of dispossession}

Partner organisations are often unaware of or uninterested in the actual identities of the people with whom they have partnered. The two groups of beneficiaries discussed here have quite different histories that stand in stark contrast to the process of generic 'community' creation outlined above. These stories are presented here in some detail, both to reveal the processes through which land reform beneficiaries are forced to take on new identities in the land reform process - in this case, identities shaped by a biodiversity conservation discourse - and to reveal how problematic and contested the beneficiaries' actual experiences of restitution can be in a contextsuch as this. 


\section{Case study 1: from 'Bhambatha's Kraal' to the Ngome Community Game Reserve}

In 2004, the Ngome Community Game Reserve near Greytown was described by the African Conservation Association in glowing terms. A successful land claim in the KwaZulu-Natal midlands', it claims, 'is about to become a successful hunting concession, with the potential for substantial income for about 600 previously- destitute families' (African Conservation Foundation 2004). Behind the headlines and photo opportunities, however, is a complex history of dispossession and at best partial restitution.

The farm, which is now part of the Ngome Community Game Reserve, was converted to game farming by its previous owners in 1974. Prior to this, the farm in question, Aangelegen, was a so-called labour farm with an absentee landowner, occupied by African families living there as labour tenants. At the time of the conversion to game farming, 15-20 labour tenant families and their cattle were evicted from the farm, leaving only three households behind in the reserve (Ngubane 2012). ${ }^{3}$ The farm then took on its new identity as 'Bhambatha's Kraal Private Game Reserve', a name heavy with irony in this context. The labour tenants who had been evicted from the land owed their allegiance to the Zondi clan whose chief - the famous Bhambatha - unsuccessfully opposed colonial authority at the start of the twentieth century, leading to the 1906 Bhambatha Rebellion (Guy 2005). The new game farm bore Bhambatha's name, but nolonger had space for Bhambatha's people.

How did the Zondi people end up as labour tenants on white-owned farms in the 'thornveld' region? These farms had their roots in the brief period of Voortrekker control of the Natal interior. The short-lived Republic of Natalia (1839-1842) made a number of land grants to trekboers who were attempting to escape British rule at the Cape. After the British took over the Natal Colony in 1843 , a decision had to be made about the validity of these land grants. It was decided to formalise the grants via a 'quit rent' system: that is, the claims were recognised as valid as long as a small annual rent was paid to the state. Later, many of these farms were converted to freehold tenure (Brooks 1996). Aangelegen was converted from quit rent to freehold tenure in 1920.

The people living on Aangelegen farm - on the lands they knew collectively as Ngome - were labour tenants. This meant that they were part of a system of economic survival that became widespread in the Natal interior from the late nineteenth century. As land outside the so-called native reserves had been privatised, many African homestead heads reached an accommodation with landowners that allowed them to maintain their homesteads and cattle on white-owned farms in exchange for the provision of labour (McClendon 1995, 2002). McClendon (1995) explains that in terms of these verbal agreements, young men worked on the farm for part of the year where they were paid 'nominal wages, if anything'. For the rest of the year, 'the men either "rested" - that is, worked on their own homesteads on the farm - or migrated to the cities, especially Johannesburg and Durban for work at considerably higher wages' (39).

In some cases, midlands farmers purchased relatively cheap and unproductive land located in the drier north-eastern (thornveld) parts of the colony at a distance from their main commercial enterprise, both to ensure a constant supply of labour (McClendon 1995) and for winter grazing for cattle (Brooks 1996). This allowed the 
landowner to concentrate his main farming activities in the more productive part of the midlands (the southern part), and keep a 'spare' farm further north. According to McClendon, 'Thornveld homesteads were subject to little supervision' $(1995,52)$. These farms were known as 'labour farms' and Aangelegen, prior to its conversion to game farming, was such a labour farm.

The Zondis gained title to Aangelegen farm in 1997 through the post-apartheid land reform process. The final settlement did not, however, transfer land title to the actual labour tenant families evicted to make way for Bhambatha's Kraal Private Game Reserve in 1974, or even to the few households that had been allowed to stay behind as workers. This was because the land claim formed part of a larger 'tribal' land claim lodged against a series of farms by the Zondi chief, Inkosi Khulekani Zondi, on behalf of a much broader Zondi community. The Zondi chief, at the forefront of the land claim, first lodged a restitution claim but was advised by the state that this would not succeed because the original dispossession of Zondi land had taken place well before the 1913 Land Act (specified in the Restitution Act as the cut-off point for claims). The chief was advised instead to work through the land redistribution programme, a route that proved successful.

The landholder since 1997 is the Ngome Community Land Trust, a CPA set-up to hold and manage the land in the interests of the land beneficiaries. Using the pooled household grants of all the listed beneficiaries, the state was able to purchase two properties - one of them Aangelegen - for the Ngome Community Game Reserve. A former project manager at the Department of Land Affairs described the early days of the land transfer from his point of view. He understood the chief to have been influential in determining the future land-use, that is, game farming:

[Inkosi Khulekani Zondi] knew those two land owners quite well. The relationship was complicated because people historically always believed that was their land, in which they were right. But he said: 'No, look, we'll keep this as a game reserve, let us have a positive relationship in terms of environmental conservation and also maybe we can earn an income from these farms'. So, that was the purpose of that claim, that application. (Interview with former DLA Project Officer, October 2010)

Inkosi Khulekani Zondi did not serve on the Trust because he recognised that, in terms of the legislation governing CPAs created through the land reform process, the traditional authority ought to maintain an appropriate distance from the new CPA (see Oomen 2005). His successors, however, were to be far more closely involved in decision-making around the 'community' game farm.

With regard to skills transfer, it seems that the previous owners were not approached by the Trust or by the Department of Land Affairs (DLA, now the Department of Rural Development and Land Reform) about the possibility of a joint venture. According to one of the former landowners:

I have never been approached, nor have the other owners of the land, nor have they ever been approached to assist with the farming. We ran a safari hunting business - 
we had a lot of professional hunters hunting there because we had very good Inyala and we had very good Kudu and Bushbuck ... We sold our cattle and we concentrated only on game - we had a lot of game. We were doing good business. (Interview with previous owner of Bhambatha's Kraal Private Game Reserve, November 2010)

The DLA did however appoint the previous manager of Bhambatha's Kraal Private Game Reserve to stay on and work with the new owners as a 'Training Consultant' to manage the game and the hunting camp. According to the manager, 'There was nobody there that could have dealt with the hunting, or hosted the international hunting clients' (Interview with former Training Consultant, September 2010).

At first this continuity seemed to pay off; but when problems began to arise, such as poaching and people 'settling too close to the boundary', the manager felt that the commercial viability of the game farm was under threat and he resigned in 1998 (Interview with former Training Consultant, September 2010). At this point the Trust and the Zondi chieftainship took the initiative in inviting other outside partners in to run the game farm. Successor chiefs to Inkosi Khulekani Zondi were less scrupulous about maintaining the independence of the Trust, the history of which has been marked by dissent and controversy. The traditional authority has played an increasingly dominant role in management decisions regarding the 'community game farm'. In brief, Inkosi Khulekani Zondi's immediate successor Sakhisizwe Zondi invited two new ('white') advisors on board, one of them the former Inkatha Freedom Party politician Walter Felgate. These advisers convinced the Trust that 'hunting is not productive enough. They recommended tourist attraction' (Interview with member of the dissolved Trust, June 2010). This ushered in a period of more intense development of the game farm, including the building of a hotel.

Inkosi Sakhisizwe however died and his successor Inkosi Mbongeleni Zondi used corruption charges against one of the advisors to ensure the dissolution of the first Ngome Community Land Trust. A new Trust was established. ${ }^{4}$ This Trust, under the leadership of the new chief, spearheaded the construction of a new luxury lodge and conference centre to the value of R7.6 million. Bhambatha Lodge was paid for by the provincial department of Economic Development and Tourism and was officially handed over to the Ngome Community Land Trust at a ceremony in May 2009. ${ }^{5}$

Currently the Ngome Community Land Trust is viewed as indistinguishable from the traditional authority. Local people see the game farm more or less as the chief's private fiefdom. Several incidents are cited by interviewees to support this view. First, in consolidating its control, action was taken by the new Trust to evict the three labour tenant homesteads who had remained in the Ngome Community Game Reserve in 1974 when the other homesteads were evicted to create Bhambatha's Kraal Private Game Reserve. Another grievance is the exclusion of commoners' cattle from the reserve:

Most of the time [the chief] does not do things transparently - he wants to be the only one benefiting. You see, [commoners'] cattle are not allowed to graze in the game 
reserve - but the chief's cattle have access inside the game reserve. (Interview with Zondi community member, June 2010)

Thirdly, Inkosi Mbongeleni Zondi is regarded as the person responsible for the erection of a fence, which has extended the Ngome Community Game Reserve and restricted access to grazing land, water and firewood resources.

The change in emphasis in the period from 1997 to the present is captured in a striking passage from an interview with a member of the first Trust. He describes a transition from Ngome as a community game reserve to becoming a traditional authority game reserve:

You see, that was not negotiated, we just saw the fence. That is because they changed the condition of the game reserve from being a community game reserve to a traditional authority game reserve. It is the traditional authority that governs here, not the beneficiaries - the owners of the land are not governing. The owners of the land are ill-treated by being oppressed by the traditional authority - that is why things are the way they are. The chairman of the Trust is involved with the traditional authority. That is why he was unable to convene a meeting with the land beneficiaries to explain what is going on. The law says the Trust must convene a meeting on a specific date and engage the community, so that the beneficiaries can express their views, in order for us to develop this [the game reserve]. That all came to an end when [the first Trust] came out of office, and the game reserve was later managed by the traditional authority. (Interview with member of the dissolved Trust, June 2010)

Unsurprisingly, there is considerable resentment on the part of many land beneficiaries towards Amakhosi [chiefs], community trusts, communal property associations and land reform in general. The labour tenant families in particular the former occupants of the farm and the direct victims of forced removal when the private game farm was created in 1974 - feel they have received no benefit from the land reform process. They contrast their situation unfavourably with that of labour tenants on the farm located next to Aangelegen, Olivefontein. This land, which used to be part of the Bhambatha's Kraal Private Game Reserve, subsequently became a game farm in its own right named Khobotho Private Game Reserve.

Unlike the Aangelegen story, the farm was claimed directly by the evictees who lodged a labour tenant claim. While the original intention was to retain game farming as the land-use after the land transfer, the Department of Rural Development and Land Reform was unwilling to purchase the game. The former owner had the wildlife shot prior to his departure. With no wildlife, and no financial basis for restocking the farm, the land has been occupied by its new owners and used for settlement and cattle keeping: Khobotho Game Reserve is no more. 


\section{Case study 2: the Boschhoek removal and Kameelkop community game farm}

The second 'community game farm' studied, Kameelkop, is located near Ladysmith in the KwaZulu-Natal midlands and is run by the Boschhoek Community Trust. The new owners of Kameelkop private game farm, the AbeKunene, have a very different history to that of the Zondi former labour tenants, both in class terms and in terms of their relationship to the land. The narrative of 'community game farming', however, works to elide these substantive differences in background and historical geography.

Unlike the Zondi labour tenants, the AbeKunene were landowners during the colonial period. The farm Boschhoek, close to Wasbank in the Ladysmith area, was bought on the open land market in the period before 1913 and was held under freehold tenure. The AbeKunene people fell victim to the apartheid state's policy of forced removal - in this case the 'clearing' of so-called black spots in areas designated for white farming - in 1968. The history of the AbeKunene community needs to be understood in the context of the emergence of a small peasantry, predominantly Christian or kholwa, within African society in the Natal and Cape Colonies from the mid-nineteenth century. 'For a brief couple of decades this group flourished and grew into a recognisable, frequently prosperous peasantry and it was from this new class of African farmers and entrepreneurs that the first African land owners came' (Surplus People Project 1983, 24; Bundy 1979).

In Natal, most land purchases by Africans were made in the interior region where land was cheaper, rather than along the coast. A group of the Kunene people, who were Swazi, moved south with their chief Sigweje and settled on mission land at Edendale outside Pietermaritzburg in the nineteenth century. The chief converted to Christianity and became a socalled kholwa chief. As such, he was not incorporated into the administrative machine of the Natal Native Trust - he was not regarded as a 'traditional' or 'tribal' chief as in the Zondi case - but was treated by the Natal government as a senior person in the kholwa community. ${ }^{6}$ With the help of the mission, Sigweje and his people identified a farm for sale in the interior region near Ladysmith and purchased it in 1870.

Under the Nationalist government, the term 'black spots' was increasingly used to refer to pieces of black-owned freehold land, which were scheduled for removal. ${ }^{7}$ The so-called black spot removal programme in Natal 'got underway seriously in northern Natal in the 1960s, with the targeting of a series of farms in the Vryheid, Newcastle and Dundee districts' (Walker 2008, 84). These removals, which often ignored title deeds held by black landowners, were not only 'bitterly opposed by the people affected' but were widely covered by the liberal press, generating negative publicity at home and condemnation abroad (Surplus People Project 1983, 102).

The AbeKunene community of Boschhoek farm was removed in 1968. An isiZulu newspaper article from the time quotes the AbeKunene chief, Inkosi Inca Kunene (the father of the current chief), as saying: 'We did not want to move. We did not approach the government and request to be removed, nor did we ask for their assistance and advice. We want to stay here, in Boschhoek' (Ilange lase Natal 1968). ${ }^{8}$ The chief at first tried to resist the removal to the resettlement camp Vergelegen, some $20 \mathrm{~km}$ away, but ultimately saw no option but to bow to the demands of the apartheid government. This outcome was never accepted by the AbeKunene community. During the apartheid era, Inkosi Inca Kunene and prominent men in 
the community explored every possible avenue for the return of Boschhoek farm. Inkosi Siphiwe Kunene took over from his father in 1989, inheriting the role of leader in the struggle for the return of thelost land.

The Boschhoek Community Trust launched a land claim under the Restitution of Land Rights Act as early as 1996 but this was only finalised in 2005. As Inkosi Kunene put it:

What we did was, we fought for the return of the land as a community. As Inkosi I had to play a vanguard role, to lodge the land claim and speak on behalf of people, based on our history, where we are originally from. I spoke on behalf of the people, based also on the Trusts, in order to ensure continuity - they know my father, grandmother and grandfather. (Interview with Inkosi Kunene, July 2010)

Two farms were awarded to the AbeKunene in the restitution agreement: Kuickvlei farm, intended for settlement purposes, and Kameelkop, a game farm about 4000 ha in size. The award of the farm Kameelkop - formerly a privately owned game farm was made as compensatory land because the original farm, Boschhoek, is now occupied by the South African National Defence Force (SANDF). The SANDF took over the land for use as a training camp in 1972, and was not prepared to release the farm for restitution. The fact that the AbeKunene community were forced to accept compensatory land as settlement of the land claim remains controversial for some community members: the importance of the original land is suggested by the choice of the name Boschhoek Community Trust as the body to administer the restitution land awarded.

Inkosi Kunene was elected chairperson of the Boschhoek Community Trust, a position he maintains until the present day although he insists that decisions are taken in a democratic manner in line with the previous practice at Boschhoek farm. It must be emphasised that the AbeKunene people have no previous experience of game farming and indeed have not engaged in any form of farming since the forced removal, as this was impossible in the relocation camp. Most are employed in professions such as teaching, nursing and the civil service, and they work in town. Theirs is thus a very different case from the Zondi labour tenants, who were deeply affected by the establishment of the Bhambatha's Kraal Private Game Reserve when their cattle-based livelihoods were fatally disturbed by the associated removals. There was initial scepticism about the game farm, which Chief Kunene and the Trust worked hard to overcome. Inkosi Kunene played a lead role in 'converting' the community to game farming:

Game farming was new to us, but we were very much interested [in business] ... When we lodged the land claim we had agreed to make the land profitable once the land claim had been settled... When we received the game farm, we received a well organised business, and we did not have to start from scratch - erection of the boundary fence, etc. Everything was there, animals were there, and even accommodation, the lodge was there. All we had to do was to come in and take 
control. My role as Inkosi was to make the community understand the importance of the game farm. (Interview with Inkosi Kunene, July 2010)

However some community members have not accepted the land settlement. The question of the return of the original land remains a live, although submerged, issue at Kameelkop and may contribute to a relatively weak sense of ownership of the game farm. The game farm belongs to the AbeKunene but is located on land to which they have no prior attachment. Not only that, but there is a counterclaim by the former labour tenants of Kameelkop, who were removed when the game farm was established and who resent their land being given to other people. Some AbeKunene community members say they like the idea of owning a game farm, but they want to move the game farm to Boschhoek.

When interviewed about his involvement at Kameelkop after the handover, the previous owner of Kameelkop Game Farm expressed some regret that he was not asked to serve as a game farming mentor to the new owners of the farm (Nqabayamaswazi Previous Owner, August 2010). The issue of racial tension was explicitly raised by an AbeKunene community member as the main factor behind the withdrawal of the previous owner from the community game farm. As he put it, At the beginning, we operated the game farm together with the previous owner. But after some time the race issue haunted us, and so he left' (Interview with AbeKunene community member, July 2009). The Boschhoek Community Trust, it can be inferred, felt little sense of ownership over the game farm in the presence of the previous owner.

While the Department of Land Affairs has provided some post-settlement support for the Kameelkop land restitution project, in recent years this appears to have declined. According to a game farm staff member:

We have told them, You Land Affairs are bad, because at the beginning when you granted us this land [the game farm], the elders said they cannot manage such a business. You then promised to come on board and assist. But now you have distanced yourselves. (Interview with Kameelkop staff member, May 2010)

The AbeKunene have made a formal complaint to the Department. For its part, the Department says it will retain a Project Officer for as long as it takes: 'When we are convinced that they can sustain themselves, we will pull out. But in my experience, I have not seen a project sustaining itself. It is highly unlikely' (Interview with Project Officer, Department of Rural Development and Land Reform, May 2010).

\section{Power dynamics in the partnerships and the economics of 'community game farming'}

The last section of the paper explores in greater depth two key aspects of the 'community game farm' as it elaborated in the context of land reform in the KwaZulu-Natal midlands. First, we look at the implications for the land beneficiaries of their partnerships with 'outside experts' and the tensions within these partnerships. A number of scholars have observed that partnerships entered into 
by land reform beneficiaries, whether with state or private sector partners, are about power and as a result, are often characterised by conflict (Kepe 2008; Ntshona et al. 2010). Game farming is no exception. We look at conflicts and difficulties within these relationships, and the response of partner organisations when they find themselves unable to exercise sufficient control over outcomes.

One of the main causes of tension within the partnerships is the expectation of a commercially viable and wealth-producing enterprise which has been set up in the process of 'imposing' game farming as a land-use on beneficiary communities. The second aspect, therefore, is the economic viability of game farming in this context. We noted earlier that the discourse of $\mathrm{CBC}$, which aims to promote conservationfriendly behaviour by making the ownership of wildlife profitable for people living on communal land, is inappropriate in the case of small game farms, such as those discussed here. It remains unclear whether private game farming does in fact constitute an economically viable prospect for large groups of land beneficiaries: as in other areas of land reform, in all likelihood the economic expectations raised cannot be met.

An issue that has arisen at both game farms is a desire on the part of the land Trusts to extend the focus away from hunting operations oriented to local South African hunters (who constitute the membership of the partner organisation KZNHCA), to try to diversify and attract other tourist business. This is the cause of significant tension in the partnership with KZNHCA. While strongly opposing the development of the Bhambatha luxury lodge at the Ngome Community Game Reserve, the hunting association was unable to prevent the Ngome Community Land Trust from going ahead with fundraising for the lodge's construction, mainly because the chief strongly supported the development.

In thinking about this tension, it is useful to refer to the distinction Cloete, Taljaard, and Grové (2007) made between local 'biltong' or meat hunters, and international trophy hunting clients who expect a different kind of safari experience. A number of private game farms in South Africa appeal to the latter clientele, offering upmarket trophy hunting and charge in US dollars. However, as a hunting client interviewed at Ngome stated, 'Most of the guys in that Association ... would be quite happy to put their tent in the bush. They don't want a luxury lodge'. Pointing to the newly constructed Bhambatha Lodge, he explained: 'They don't want to stay in a place like that lodge over there ... they want to sit around a fire at night and hear the jackals and not hear a generator making electricity' (Interview with hunting client, Ngome Community Game Reserve, August 2010).

Like the Ngome Community Land Trust, the Boschhoek Community Trust too wanted to undertake projects at their game farm, which the partner organisation felt were not in its interests. A proposal by the Boschhoek Community Trust to build a conference centre on Kameelkop Community Game Farm was vetoed by KZNHCA and there is a lingering feeling of resentment about this. Some of the beneficiaries hold the view that the hunting association tries to dominate the partnership too much, hampering the Trust in its efforts to develop the property. As a staff member 
at Kameelkop Community Game Farm put it, 'They [KZNHCA] tend to dislike state departments that offer us some help, and claim that there is no need for such development' (Interview with Kameelkop staff member, July 2009). The hunting association, for its part, remains frustrated with the Boschhoek Community Trust, feeling that there is insufficient understanding of what is involved in running a game farm. As an official put it, "We are still battling ... to try and change their point of view with regards to how important it is to manage, utilise and sustain Kameelkop, and improve in tackling the projects that we suggest that they must do' (Interview with KZNHCA official, July 2010, our emphasis).

The partnership between KZNHCA and the Boschhoek Trust was tested in the winter of 2010, when Kameelkop Community Game Farm was hit by a serious fire which devastated the farm (Northern KwaZulu-Natal Courier 2010). Aware that the game animals would die if they did not receive supplementary feeding during this winter season, KZNHCA opted not to wait for the aid promised by various government departments (which did not in fact materialise), but took the initiative to provide supplementary feeding. The cost of feeding rose steeply, leaving the Boschhoek Community Trust heavily indebted to the hunting association. Unfortunately, just a few weeks before the fire, the Boschhoek Community Trust had purchased cattle which they hoped to integrate with wildlife at the game farm. The KZNHCA sees the purchase of cattle as a waste of community funds that could have been utilised after a fire disaster, such as that which befell the game farm in July 2010:

... it's important that the money gets ploughed back to Kameelkop - the income from this place, because if you look at the books, the community bought R87 ooo worth of cattle that could have been used for this problem [devastation by fire] that we have here now. I can understand if there is enough money, enough funds, they can buy cattle and obviously sell the cattle and get money from there as well. [But] Kameelkop money should be invested in Kameelkop and maybe not cattle. The focus I think in some areas is not where it should be. We have discussed this with Inkosi, he understands. (Interview with KZNHCA official, July 2010)

KZNHCA maintains a relatively close relationship with the owners of the Kameelkop Community Game Farm. However, in the case of the association's partnership with the Ngome Community Land Trust, tensions have become acute. According to KZNHCA, the problems are partly a reflection of unreasonably high expectations on the part of land beneficiaries, who expect immediate returns. They often query the money generated from the hunting operation and put pressure on the Ngome Community Land Trust. The Trust then complains to KZNHCA, and so the vicious cycle continues. As the KZNHCA official put it:

They want money now. If the [hunter's] car leaves on Sunday, on Monday they phone me, 'where is the money?' From Bhambatha's [Ngome Community Game Reserve] there is a lot of mistrust. 'But where is the money, there must be more!' They [the members of the Trust] get pressure from the local community, that say: 'There are a lot of people driving out of here with game in their vehicles, but why don't we have a job, why is there 
not more game guards, why is there nobody running the lodge, why are we local people not getting the benefit? (Interview with KZNHCA official, August 2010)

This vivid description raises an important issue with regard to the game farms transferred to land beneficiaries in KwaZulu-Natal. Are they commercially viable and can they offer financial returns to beneficiary communities? Have unrealistic expectations been created? These new 'community game farms', after all, are meant to be a business in which income is generated through wildlife production and the hunting industry; biodiversity conservation concerns are secondary. Only a few members of the community can be directly employed to work in the reserves as game guards or hunting guides, and yet many hundreds of families are also intended beneficiaries.

Bothma et al. (2009, 157) estimate that 'approximately half of all South African wildlife ranches are owned on a part-time basis by professional people ... and are generally unprofitable'. Thirteen years after the land transfer, the former DLA Project Officer at Ngome reflected on the fact that it was perhaps unreasonable to have expected a beneficiary community of more than five hundred people to have realised meaningful benefits from 'community game farm' land which was once a family business or even a leisure farm (Interview with former DLA Project Officer, October 2010). In the case of Aangelegen farm and its neighbour Olivefontein, the arms had not previously been anyone's main livelihood. In the interview with the former manager of Bhambatha's Kraal Private Game Reserve, we were assured that the land had previously made significant money through its hunting operations (Interview with former Training Consultant, September 2010). This may be the case; but the former DLA Project Officer put this in context, noting that the previous owners - a successful lawyer and doctor living in Durban - were 'using them [the game farms] as a weekend thing. They were not worried about the income that they generated there'. As he admitted, 'It's a completely different thing when you've got a community that's trying to earn an income out of the same kind of operation' (Interview with former DLA Project Officer, October 2010).

This is a crucial point and one that appears to have been insufficiently thought through by the proponents of the small 'community game farms' emerging from the land reform process. Aside from issues of skills transfer and management expertise, the economic viability of small hunting farms expected to generate revenue for whole communities needs to be explored in more detail.

These frustrations have resulted in the partner organisation considering options that would enable it to gain greater de facto control of the game farm spaces. The priority from the hunting association's point of view is to find land-owning partners who can offer viable hunting packages to its members. The latter travel to a range of game farms in the province for leisure hunting purposes. From the point of view of KZNHCA, land reform carries with it the possibility that large portions of this land will not remain under game farming. The organisation's involvement with the community game farms is presented to its hunters in terms of a 'social responsibility' agenda - hunters are offered the opportunity to hunt at a community game farm and thereby make a contribution to 'community' upliftment (KwaZulu-Natal Hunting and Conservation Association 2009). However the organisation's fear that game farms previously available to its members may be 'lost' to land reform, puts the altruistic aspects of this 
involvement in context. Involvement in the partnerships and involvement in skills transfer would, it was hoped, enable the game farms to keep running, whilst allowing the partner organisation to exercise considerable influence over management decisions.

Following serious disagreements with some land Trusts, KZNHCA has recently taken the initiative in forming a new Trust of its own, Nemvelo. ${ }^{9}$ In forming Nemvelo, KZNHCA appears to be positioning itself as in some sense the 'saviour' of the new category of conservation land emerging in KwaZulu-Natal, namely the game farms emerging from the land reform process. A KZNHCA official pointed out that there are now 32 beneficiated game farms in the province, constituting about 100,000 hectares of land - a substantial area. And KZNHCA alone, he claims, is paying attention to a sector that, unlike the state protected areas,

... nobody is funding .. . Nobody teaches them how to run it, how to generate money, how to maintain it, how to get people there. Nobody understands marketing, nobody understands finance. And let me tell you, if it stays like that, there will be an uprising. (Interview with KZNHCA official, August 2010)

It is not impossible that Nemvelo Trust may soon undertake closer management of the community game farms under study, as well as others in various parts of the province.

\section{Conclusion}

This article has provided a multi-layered analysis of the experience of post-apartheid land beneficiaries on private conservation land. In exploring the complex historical geographies of two groups of claimants who received private game farms as part of the land reform process, it aimed to highlight the way in which the new category of 'community game farm' works to refashion these complex and very different stories into a generic 'community'; a 'community' of poor black people who can then be initiated into the ideology of $\mathrm{CBC}$. The evidence suggests that the narrative of biodiversity conservation and $\mathrm{CBC}$ is functional for various state and private sector partner organisations that have helped shape this new identity for land beneficiaries. This set of ideas, developed to improve natural resource management on communal land is not, however, usefully applied to small pieces of freehold land, such as hunting farms, previously owned by a single freehold landowner. Its application in these contexts may even be damaging.

The article has also been concerned to probe the motivations of these various 'partners' and the extent to which their involvement has shaped land reform outcomes. For the provincial conservation agency, the continuation of game farming on beneficiated land must be promoted in the face of alternative scenarios of settlement or livestock farming - neither of which supports biodiversity protection. For the hunting association, continuity with the previous land-use means that the farms remain accessible to its members, who can continue to hunt there. From the point of view of the Department of Rural Development and Land Reform, the economic returns promised by the game farming sector suggest that this is an economically viable form of production that can sustain beneficiary groups. For the land trusts and the traditional authorities who have effective control of the land, too, the 'community game farm' is a success story. 
However, a number of land beneficiaries see this as a story of loss and misfortune, and they express disappointment in land reform. To paraphrase the anthropologist Greg Dening, it is useful to make a distinction here between the 'real' and the 'actual'. As Dening commented in another context, his concern was not for the obvious or apparent reality of what had taken place: he did 'not care so much about what really happened'. However, About what actually happened, I do [care]' (Dening 1993, 77). We know the 'real' beneficiaries in this story - this article has described their specific histories of dispossession, and the transfer of land through the state land reform process is a documented matter of public record. The question we are posing here is a less obvious and more provocative one: who are the actual beneficiaries of the 'community game farm'?

\section{Acknowledgements}

The authors gratefully acknowledge financial support from the University of the Free State Research Cluster, 'New Frontiers in Poverty Reduction and Sustainable Development', as well as the personal support of the Cluster director, Doreen Atkinson. The authors also benefited from participation in two interrelated collaborative research projects: 'Farm Dwellers, the Forgotten People? Consequences of Conversions to Private Wildlife Production in KwaZulu- Natal', funded by the South Africa Netherlands Research Programme on Alternatives in Development; and the extended version of that project, 'Farm Dwellers, the Forgotten People? Consequences of Conversions to Private Wildlife Production in KwaZulu-Natal and the Eastern Cape', funded by NWO-WOTRO (NWO is the Netherlands Organization for Scientific Research, partnered with WOTRO Science for Global Development in the NOW-WOTRO research programme). We are most grateful to all the research participants in KwaZulu-Natal. We would also like to acknowledge the input and insightful comments of several careful readers: Gillian Hart of the University of California at Berkeley, Thembela Kepe of the University of Toronto, Lindokhuhle Khumalo of the University of the Western Cape, Jenny Josefsson of the University of the Free State, Robin Palmer of Rhodes University, Robert Gordon of the University of Vermont (currently based at the University of the Free State), and Marja Spierenburg of the Vrije Universiteit, Amsterdam. Any errors of fact or interpretation are those of the authors. Thanks to Frank Sokolic for drawing the map. 


\section{Notes}

1. These developments are significant in terms of land area, as well as economic turnover. For facts and figures on the game farming industry in South Africa [albeit some years old, see NAMC (2006)].

2. The research methodology involved close engagement over several months at the two field sites, as well as targeted interviews with present and past role-players in the story. An initial period of fieldwork was conducted in July 2009 and this was extended with longer periods of fieldwork at both research sites during 2010. All interviews were conducted by Mnqobi Ngubane. Interviews were conducted either in English or isiZulu, as appropriate. All translations from the Zulu are done by Mnqobi Ngubane. For a detailed discussion of the research methodology, see the Masters dissertation in which these findings were first presented (Ngubane 2012). The research was carried out at the University of the Free State under the supervision of Shirley Brooks, now based at the University of the Western Cape.

3. The authors have taken the decision not to provide a detailed citation linking each piece of research information to the unpublished Masters dissertation where they were first presented (Ngubane 2012). It was felt that this would be too cumbersome and interrupt the flow of the article. The dissertation is however available for consultation.

4. For a recent in-depth consideration of similar disputes over land trusts to whom (in this case, state) conservation areas have been transferred - albeit in other part of the country - see Fay (2013).

5. The construction of the Bhambatha Lodge went ahead against the advice of the partner organisation, the KwaZulu-Natal Hunters and Conservation Association. Its construction caused tensions within the partnership, discussed in the last section of the article.

6. Thanks to Jeff Guy for this insight into the historical figure of the kholwa chief.

7. Bill Freund put this well almost 30 years ago when apartheid-era removals were still ongoing: 'Black spots are, as the name implies, islands of black tenure in supposedly white zones. They have in general belonged to the more prosperous strata of the African peasantry who had been able, when it was legal before the land division of 1913, to purchase freehold property, often through companies of ex-wage workers or the agency of the missions' (Freund 1984, 51).

8. Translation from isiZulu by Mnqobi Ngubane.

9. Like the provincial conservation agency's name (Ezemvelo KZN Wildlife), this name is also derived from the Zulu word for 'nature'. 


\section{References}

African Conservation Foundation. 2004. First SA Land Claim Set Aside for $\begin{array}{llll}\text { Conservation. } & \text { Accessed } & \text { May } & 25,\end{array}$ http://mail.africanconservation.org/wildlife-news/item/first-sa-land- claimset-aside-for-conservation

Association for Rural Advancement (AFRA). 2003. Investigation of the Effects of Conservation and Tourism on Land Tenure and Ownership Patterns in KwaZulu-Natal. Unpublished Report, Phase 1, September 15. Pietermaritzburg: McIntosh Xaba \& Associates.

Association for Rural Advancement (AFRA). 2004. Communities, Conservation, Ecotourism and Tenure Security Workshop Report. Accessed November 12, 2010. http://www.afra.co.za/ upload/files/AP19.pdf

Blaikie, P. 2006. "Is Small Really Beautiful? Community-Based Natural Resource Manage- ment in Malawi and Botswana." World Development 34 (11): 19421957. doi:10.1016/j.worlddev.2005.11.023

Bothma, J., P. du, H. Suich, and A. Spenceley. 2009. "Extensive Wildlife Production on Private Land in South Africa." In Evolution and Innovation in Wildlife Conservation: Parks and Game Ranches to Transfrontier Conservation Areas, edited by B. Child, H. Suich and A. Spenceley, 147-162. London: Earthscan.

Brooks, S. 1996. An Historical Overview of the KwaZulu-Natal Pilot Land Reform District, 180o-1996. Unpublished Status Quo Report, KwaZulu-Natal Pilot Land Reform Programme. Pietermaritzburg: Department of Land Affairs.

Brooks, S., M. Spierenburg, L. van Brakel, A. Kolk, and K. B. Lukhozi. 2011. "Creating a Commodified Wilderness: Tourism, Private Game Farming, and 'Third Nature' Landscapes in KwaZulu-Natal." Tijdschrift Voor Economische en Sociale Geografie [Journal of Economic and Social Geography] 102 (3): 260-274. doi:10.1111/j.1467-9663.2011.00662.x Bundy, C. 1979. The Rise and Fall of the South African Peasantry. London: Heinemann.

Carruthers, J. 2008. "Wilding the Farm or Farming the Wild?' The Evolution of Scientific Game Ranching in South Africa from the 1960s to the Present." Transactions of the Royal Society of South Africa 63 (2): 160-181. doi:10.1080/00359190809519220

Cloete, P. C., P. R. Taljaard, and B. Grové. 2007. "A Comparative Economic Case Study of Switching from Cattle Farming to Game Ranching in the Northern Cape Province." South African Journal of Wildlife Research 37 (1): 71-78. doi:10.3957/0379-4369-37.1.71

Cousins, J. A., J. P. Sadler, and J. Evans. 2008. "Exploring the Role of Private Wildlife Ranching as a Conservation Tool in South Africa: Stakeholder Perspectives." Ecology and Society 13 (2): 43. http://www.ecologyandsociety.org/vol13/iss2/art43/

Dening, G. 1993. "The Theatricality of History Making and the Paradoxes of Acting." Cultural Anthropology 8 (1): 73-95. doi:10.1525/can.1993.8.1.02a00040 Fabricius, C., E. Koch, and H. Magome. 2001. "Towards Strengthening Collaborative Ecosystem Management: Lessons from Environmental Conflict and Political Change in Southern Africa." Journal of the Royal Society of New Zealand 31 (4): 831-844. doi:10.1080/03014223.2001.9517679 
Fay, D. 2013. "Neoliberal Conservation and the Potential for Lawfare: New Legal Entities and the Political Ecology of Litigation at Dwesa-Cwebe, South Africa." Geoforum 44: 170-181. doi:10.1016/j.geoforum.2012.09.012

Freund, B. 1984. "Forced Resettlement and the Political Economy of South Africa." Review of African Political Economy $11 \quad$ (29): 49-63. doi:10.1080/03056248408703567

Guy, J. 2005. The Maphumulo Uprising: War, Law and Ritual in the Zulu Rebellion. Pietermaritzburg: University of KwaZulu-Natal Press.

Hart, G., and M. Hunter. 2004. Women and Juniors as Historical Agents: Natal 1920s-1940s. Review of Genders and Generations Apart: Labor Tenants and Customary Law in Segregation-Era South Africa, 1920s to 1940s, by T.V. McClendon. Journal of Southern African Studies 30 (4): 915-917. http://web.ebscohost.com.ezproxy.uwc.ac.za/ehost/pdfviewer/pdfviewer?sid=4271 133d-b6f6-4db3-9618-bbee6ee5be2d\%40sessionmgr110 :vid=4\&hid=122

Hebinck, P., D. Fay, and K. Kondlo. 2011. "Land and Agrarian Reform in South Africa's Eastern Cape Province: Caught by Continuities.” Journal of Agrarian Change 11 (2): 220-240. doi:10.1111/j.1471-0366.2010.00297.x

Hulme, D., and M. Murphree, eds. 2001. African Wildlife and Livelihoods: The Promise and Performance of Community Conservation. Oxford: James Currey. Ilange lase Natal. 1968. "Sithuthiwe isizwe sikaKunene [Kunene's people relocated]." Ilanga Newspaper August 24. Accessed in Killie Campbell Africana Library Collections, Durban.

Kepe, T. 2008. "Land Claims and Comanagement of Protected Areas in South Africa: Exploring the Challenges." Environmental Management 41 (3): 311321. doi:10.1007/ s00267-007-9034-x

Kepe, T., R. Wynberg, and W. Ellis. 2003. Land Reform and Biodiversity Conservation in South Africa: Complementary or in Conflict? No. 25 in Occasional Paper Series, Land Reform and Agrarian Change in Southern Africa. Cape Town: Programme for Land and Agrarian Studies, University of the Western Cape. http://www.plaas.org.za/sites/default/files/publica- tions-pdf/OP\%2025.pdf

KwaZulu-Natal Hunting and Conservation Association. 2009. "Social Responsibility." Accessed March $\quad 1, \quad 2009$. http://www.kznhunters.co.za/site/awdep.asp?depnum=29367 Lahiff, E. 2009. "With What Land Rights? Tenure Arrangements and Support." In Another Countryside? Policy Options for Land and Agrarian Reform in South Africa, edited by R. Hall, 92-117. Cape Town: Institute for Poverty, Land and Agrarian Studies, University of the Western Cape.

Lindsey, P. A., S. S. Romañ ach, and H. T. Davies-Mostert. 2009. "The Importance of Conservancies for Enhancing the Value of Game Ranch Land for Large Mammal Conservation in Southern Africa." Journal of Zoology 277 (2): 99-105. doi:10.1111/j.1469-7998.2008.00529.x

Logan, B. I., and W. G. Moseley. 2002. "The Political Ecology of Poverty Alleviation in Zimbabwe's Communal Areas Management Programme for Indigenous Resources (CAMPFIRE)." Geoforum 33 (1): 1-14. doi:10.1016/Soo167185(01)00027-6

Manjengwa, J. 2006. Natural Resource Management and Land Reform in Southern Africa. No. 15 in Occasional Paper Series, Commons Southern Africa. Cape 
Town: Centre for Applied Social Sciences and Programme for Poverty, Land and Agrarian Studies, University of the Western Cape.

McClendon, T. V. 1995. "Genders and Generations Apart: Labour Tenants, Law and Domestic Struggle in Natal, South Africa, 1918-1944." PhD diss., Stanford University.

McClendon, T. V. 2002. Genders and Generations Apart: Labor Tenants and Customary Law in Segregation-Era South Africa, 1920 s to 1940 . Portsmouth: Heinemann; Oxford: James Currey.

National Agricultural Marketing Council (NAMC). 2006. Report on the Investigation to Identify Problems for Sustainable Growth and Development in South African Wildlife Ranching. Pretoria: NAMC. http://www.namc.co.za/dnn/LinkClick.aspx?fileticket=

HS7BSMTKAZY\%3D\&tabid=72\&mid $=542$

Northern KwaZulu-Natal Courier. 2010. "Devastation: Animals Left Stricken after Ravaging Fire.” Northern KwaZulu-Natal Courier July 23.

Ngubane, M. 2012. "Land Beneficiaries as Game Farmers in the 'New' South Africa: Land Reform in Relation to Conservation, the Hunting Industry and Chiefly Authority in KwaZulu-Natal."MA diss., University of the Free State.

Ntshona, Z., M. Kraai, T. Kepe, and P. Saliwa. 2010. "From Land Rights to Environmental Entitlements: Community Discontent in the 'Successful' DwesaCwebe Land Claim in South Africa." Development Southern Africa 27 (3): 353-361. doi:10.1080/0376835X.2010.498942

Oomen, B. 2005. Chiefs in South Africa: Law, Power and Culture in the PostApartheid Era. Oxford: James Currey; Pietermaritzburg: University KwaZuluNatal Press.

Ramutsindela, M. 2003. "Land Reform in South Africa's National Parks: A Catalyst for the Human-Nature Nexus." Land Use Policy 20 (1): 41-49. doi:10.1016/So2648377(02)oo054-6 Ramutsindela, M. F. 2002. "The Perfect Way to Ending a Painful Past? Makuleke Land Deal in South Africa." Geoforum 33 (1): 15 (01)00008-2

Reid, H. 2001. "Contractual National Parks and the Makuleke Community." Human Ecology 29 (2): 135-155. doi:10.1023/A:1011072213331

Surplus People Project. 1983. Forced Removals in South Africa, Volume 4: Natal. Cape Town: Surplus People Project.

Tyman, C. 2000. "Participatory Conservation? Community-Based Natural Resource Manage- ment in Botswana." The Geographical Journal 166 (4): 323-335. doi:10.1111/j.1475-4959.2000.tbooo34.x.

Walker, C. 2008. Landmarked: Land Claims and Land Restitution in South Africa. Athens, OH: Ohio University Press; Johannesburg: Jacana. 